\title{
RECHTSREGEL
}

Jurnal Ilmu Hukum Vol 1, No 1 Agustus 2018

P-ISSN 2622-6235, E-ISSN 2622-6243,

rjih_fh@unpam.co.id

\section{KAJIAN TEORISTIS PERLINDUNGAN HUKUM PERJANJIAN WARALABA DIKAITKAN DENGAN ASAS KEBEBASAN BERKONTRAK \\ (Studi Kasus Di C.V Rocket Fried Chicken)}

Fithry Khairiyati

Fakultas Ilmu Hukum, Universitas Pamulang

Email : fithry.khairiyati@gmail.com

Received: - /Revised: - / Accepted: Ags 2018

\begin{abstract}
Ekspansi dunia bisnis telah menembus batas ruang, waktu dan territorial suatu negara. Salah satu terobosan yang dilakukan oleh pelaku bisnis adalah pengembangan usaha melalui sistem franchise yang di Indonesia diistilahkan dengan waralaba. Peraturan Pemerintah RI No. 42 Tahun 2007 tentang Waralaba memberikan defenisi Waralaba adalah hak khusus yang dimiliki oleh orang perseorangan atau badan usaha terhadap sistem bisnis dengan ciri khas usaha dalam rangka memasarkan barang dan/atau jasa yang telah terbukti berhasil dan dapat dimanfaatkan dan/atau digunakan oleh pihak lain berdasarkan perjanjian waralaba. Di Indonesia aturan hukum mengenai Waralaba (Franchise) belum lengkap, mengingat pengaturan melalui undangundang belum tersentuh oleh pemerintah. Hal ini diperlukan untuk menghindari pelaku usaha waralaba dari kerugian yang tidak diinginkan karena belum lengkapnya perangkat hukum yang melindungi mereka. Perjanjian waralaba merupakan perjanjian istimewa bagi para pihak yang terikat di dalamnya, karena berkaitan dengan hak-hak kekayaan intelektual yang telah terdaftar.
\end{abstract}

Kata Kunci : Waralaba, Perlindungan Hukum

\section{ABSTRACT}

Business expansion has penetrated the boundaries of space, time and territorial of a country. One of the breakthroughs done by the business is the development of business through a franchise system in Indonesia termed the franchise. RI Government Regulation no. 42 of 2007 concerning Franchises to grant a Franchise definition is a special right owned by an individual or a business entity to a 
business system with a business characteristic in order to market goods and / or services that have proven successful and can be utilized and / or used by another party under the agreement franchise. In Indonesia the rule of law on Franchise (Franchise) is not complete, considering the arrangement through the law has not been touched by the government. This is necessary to avoid franchisees from undesirable losses due to the incomplete set of laws protecting them. The franchise agreement is a special treaty for the parties to which it relates, as it relates to registered intellectual property rights.

\section{Keywords: Franchising, Legal Protection}

\section{PENDAHULUAN}

Waralaba pada hakekatnya adalah sebuah konsep pemasaran dalam rangka memperluas jaringan usaha secara cepat. Waralaba bukanlah sebuah alternative melainkan salah satu cara yang sama kuatnya dan strateginya adengan cara konvensional dalam mengembangkan usaha. Bahkan system waralaba dianggap memiliki banyak kelebihan terutama menyangkut pendanaan, sumber daya manusia (SDM) dan manajemen.Waralaba juga dikenal sebagai jalur distribusi yang sangat efektif untuk mendekatkan produk kepada konsumennya melalui tangan-tangan penerima waralaba. ${ }^{1}$

Konsep bisnis waralaba akhir-akhir ini telah menjadi salah satu pusat perhatian sebagai bentuk terobosan pengembangan usaha. Mengingat usaha yang diwaralabakan adalah usaha-usaha yang telah teruji dan sukses dibidangnya, sehingga dianggap dapat "menjamin" mendatangkan keuntungan, faktor ini yang kemudian menjadi magnet untuk menarik animo masyarakat secara luas. Melalui konsep waralaba seseorang tidak perlu memulai usaha dari nol, karena telah ada system yang terpadu dalam waralaba,

\footnotetext{
${ }^{11}$ Majalah Info Franchise, www.majalahfranchise.com, 16 Juni 2008, Diakses, 25 Mei 2016.
} 
yang memungkinkan seorang penerima waralaba menjalankan usaha dengan baik. Setidaknya dalam tiga tahun terakhir animo masyarakat Indonesia terhadap munculnya peluang usaha waralaba sangat signifikan. Animo ini terrefleksi pada 2(dua) cermin yakni: jumlah pembeli waralaba dan jumlah peluang usaha (business opportunity) yang terkonversi menjadi waralaba. Waralaba atau dalam Bahasa Inggris disebut franchise sendiri berasal dari Bahasa Latinnya kni francorumrex yang artinya"bebas dari ikatan"yang mengacu pada kebebasan untuk memiliki hak usaha.

Pengertian Franchising (pewaralabaan) sendiri adalah perikatan dimana salah satu pihak diberikan hak untuk memanfaatkan dana atau menggunakan hak atas kekayaan intelektual atau penemuan atau ciri khas usaha yang dimiliki pihak lain dengan suatu imbalan berdasarkan persyaratan yang ditetapkan dalam rangka penyediaan dan atau penjualan barang atau jasa. Secara sederhana, benang merah waralaba adalah penjualan paket usaha komprehensif dan siap pakai yang mencakup merek dagang, material dan pengolaan manajemen. ${ }^{2}$

Waralaba bukanlah suatu industri baru bagi Indonesia, legalitas yuridisnya sudah dikenal di Indonesia sejak tahun 1997 dengan dikeluarkannya Peraturan Pemerintah RI No.16 Tahun1997 tanggal 18 Juni 1997 tentang Waralaba, yang disusul dengan Keputusan Menteri Perindustrian dan Perdagangan Republik Indonesia Nomor: 259/MPP/Kep/7/1997 tanggal 30 Juli1997 tentang Ketentuan dan Tata Cara Pelaksanaan Pendaftaran Usaha Waralaba. Peraturan ini kemudian dirubah dengan Peraturan Pemerintah Republik Nomor 42 Tahun 2007

${ }^{2}$ Majalah Info Franchise, www.majalahfranchise.com, 16 Juni 2008, Diakses, 25 Mei 2016. 
tentang Waralaba dan Peraturan Menteri Perdagangan Republik Indonesia Nomor 31/M-DAG/PER/8/2008 tentang Penyelenggaraan Waralaba. Namun menurut Gunawan Widjaja pengaturan mengenai waralaba di Indonesia tidaklah seketat di negaranegara lain, seperti di Amerika Serikat, yang mengatur waralaba dalam berbagai peraturan perundang-undangan seperti ketentuan Federal yang diatur dalam Titel 16, Chapter 1 Federal Trade Commission (FTC), Sub Chapter D Part 436 tentang Disclosure Requirements And Prohibitions Concerning Franchisin And Business Opportunity Ventures maupun dalam aturan Negara bagian (State) berdasarkan pada Uniform Franchise and Business Opportunitie Act (UFBO). ${ }^{3}$

Waralaba dalam perspektif Hak Kekayaan Intelektual adalah suatu pemberian lisensi atau hak untuk memanfaatkan, menggunakan secara bersama-sama dua jenis Hak Kekayaan Intelektual tertentu, yaitu Merek (termasuk merek dagang, merek jasa dan indikasiasal) dan Rahasia Dagang. Hak pemanfaatan dan penggunaan kedua jenis Hak Kekayaan Intelektual tersebut tidak dapat dipisahkan. Dalam hal Hak Kekayaan Intelektual yang diberikan hanyalah hak untuk menjual atau mendistribusikan produk barang atau jasa dengan menggunakan merek tertentu saja, yang tidak disertai dengan kewenangan dan atau tindakan untuk melakukan suatu hal tertentu baik dalam bentuk pengelolaan atau pengolahan lebih lanjut yang memberikan tambahan nilai pada produk barang yang dijual tersebut, maka hal yang demikian tidak jauh berbeda dari suatu bentuk pendistribusian arang ${ }^{4}$. Dengan demikian HAKI merupakan unsur

\footnotetext{
${ }^{3}$ Gunawan Widjaja, SalamFrinchise.com, 8April 2008, Diakses 28 Mei 2016.

${ }^{4}$ Gunawan Widjaja, SalamFrinchise.com, 8 April 2008, Diakses 28 Mei 2016.
} 
yang sangat signifikan dalam waralaba tanpa ada HAKI yang terdapat dalam waralaba maka dapat dikatakan suatu usaha bukanlah waralaba, oleh karena itu perlindungan hukum HAKI dalam perjanjian waralaba menjadi sangat penting dalam mendukung usaha waralaba.Waralaba sebagai subsector perdagangan memerlukan perlindungan yang memadai.

Syarat menjadi pemberi waralaba yang menjalankan system waralaba adalah mempunyai HAKI yang terdaftar di Departemen Hukum dan HAM. Oleh karena itu dapat dipastikan apabila HAKI dari pemilik waralaba tidak terdaftar maka usahanya tidak akan dapat dikembangkan dalam bentuk waralaba dan tidak terlindungi secara hukum. Berdasarkan uraian di atas, dapat diketahui bahwa HAKI dalam waralaba merupakan unsur yang terpenting, mengingat apabila suatu usaha waralaba tidak memilki HAKI tertentu maka dapat dipastikan usaha tersebut bukanlah waralaba, dengan demikian HAKI dalam waralaba harus mendapatkan perlindungan hukum, dalam hal ini perjanjian waralaba menjadi sangat signifikan dan menentukan dalam memberikan perlindungan hukum tersebut, melalui perjanjian waralaba tersebut berbagai aspek perlindungan terhadap HAKI diatur dan disepakati oleh para pihak. Oleh karena itu penulis tertarik untuk meneliti lebih lanjut mengenai tinjauan hukum terhadap perlindungan HAKI dalam perjanjian waralaba dalam bentuk penulisan tesis.

\section{PERMASALAHAN}

Berdasarkan latar belakang masalah dapat dirumuskan permasalahan yaitu: 
1. Bagaimanakah perlindungan hukum perjanjian waralaba CV. Rocket Fried Chicken dikaitkan dengan asas kebebasan berkontrak?

2. Kendala-kendala apa yang timbul dari perjanjian waralaba dikaitkan dengan asas kebebasan berkontrak?

\section{METODOLOGI PENELITIAN}

Penelitian hukum merupakan suatu kegiatan ilmiah yang didasarkan pada metode, sistematika dan pemikiran tertentu yang bertujuan untuk mempelajari satu atau beberapa gejala hukum tertentu dengan jalan menganalisanya. Kecuali itu maka juga diadakan pemeriksaan mendalam terhadap fakta hukum tersebut untuk kemudian mengusahakan suatu pemecahan atas permasalahan-permasalahan yang timbul di dalam gejala-gejala yang bersangkutan. Penelitian ini adalah penelitian yuridis empiris, oleh karena metode penelitian yang digunakan metode penelitian kualitatif, maka data yang diperlukan berupa data sekunder atau data kepustakaan dan dokumen hukum yang berupa bahan-bahan hukum. Penelitian normative tersebut dilakukan dengan meneliti bahan pustaka atau data sekunder, seperti: peraturan perundang- undangan, teori-teori hukum, dan pendapat para sarjana hukum terkemuka.

\section{PEMBAHASAN}

Perlindungan Hukum Perjanjian Waralaba bagi Pemberi Waralaba dan Penerima Waralaba

Hak Kekayaan Intelektual dalam pemberian waralaba dengan beranjak pada rumusan, pengertian dan konsep waralaba di Indonesia yang telah dijelaskan di atas dapat diketahui bahwa 
dalam pemberian waralaba senantiasa terkait pemberian hak untuk menggunakan dan atau memanfaatkan Hak Kekayaan Intelektual tertentu, yang dalam hal ini terwujud dalam bentuk:

1) Merek, baik yang meliputi merek dagang maupun merek jasa, ataupun indikasi asal (indication of origin) tertentu;

2) Suatu bentuk format, formula, ciri khas, metode, tata cara, prosedur, sistem dan lain sebagainya yang bersifat khas yang terkait dengan, dan yang tidak dapat dipisahkan dari setiap output atau produk yang dihasilkan dan selanjutnya dijual, diserahkan atau diperdagangkan dengan mempergunakan merek dagang, merek jasa atau indikasi asal tersebut di atas, yang dinamakan dengan Rahasia Dagang.

Dari kedua jenis Hak Kekayaan Intelektual tersebut, selalu dan senantiasa terdapat unsur pembeda antara waralaba yang satu dengan waralaba yang lainnya. Unsur pembeda tersebut terletak dalam sifat, bentuk dan jenis Hak Kekayaan Intelektual yang diwaralabakan. Dalam pemberian lisensi Merek, sudah dengan tegas menyebutkan bahwa Merek yang dilisensikan adalah Merek yang harus mempunyai perbedaan dengan merek-merek lainnya yang telah terdaftar pada Kantor Merek dan karenanya memperoleh perlindungan dalam hukum tersendiri. Merek-merek yang tidak terdaftar, selama belum dilakukan pendaftaran oleh pihak lain masih dapat dipergunakan secara bebas, namun dengan batasan bahwa segera setelah merek-merek tersebut telah didaftarkan, maka tidak ada hak lagi bagi pihak lain untuk mempergunakan merek tersebut selain pemilik terdaftar dan mereka yang memperoleh hak lebih lanjut.

Apabila kita cermati Peraturan Pemerintah Nomor 42 Tahun 2007 tentang Waralaba, terdapat beberapa konsep perlindungan 
hukum terhadap usaha waralaba, yaitu:

1) Pasal 3 huruf f yang menyebutkan bahwa waralaba harus merupakan suatu hak kekayaan intelektual yang sudah terdaftar. Sehingga terdapat kepastian hukum dalam bisinis waralaba, menghilangkan keragu-raguan akan waralaba yang ditawarkan;

2) Terdapatnya ketentuan yang mengharuskan dibuatnya perjanjian waralaba dalam Bahasa Indonesia;

3) Keharusan pemberi waralaba untuk memberikan prospektus sebelum membuat perjanjian waralaba, sehingga sangat melindungi kepentingan calon penerima waralaba. Adanya aturan ini memberikan ruang bagi calon penerima waralaba untuk terlebih dahulu mempelajari waralaba yang bersangkutan;

4) Ada keharusan untuk mencantumkan klausula minimal dalam perjanjian waralaba, hal ini akan menciptakan keseimbangan posisi para pihak dalam perjanjian sekaligus memberikan perlindungan hukum.

\section{Hambatan dalam Perlindungan Hukum Perjanjian Waralaba}

Berdasarkan Peraturan Menteri Perdagangan No. 12/MDag/ Per/3/2006 tentang Ketentuan dan Tata Cara Penerbitan Surat Tanda Pendaftaran Usaha Waralaba, maka anggapan penerima waralaba dilarang mengalihkan know how yang diterimanya kepada pihak lain menjadi kurang tepat, sebab Pasal 3 Permendag tersebut membolehkan perjanjian waralaba disertai pemberian hak untuk membuat perjanjian waralaba lanjutan. Artinya, pendapat yaitu secara absolut menolak penerima waralaba untuk mengalihkan know how (salah satu elemen dalam HAKI) yang 
diterimanya kepada pihak lain, bertentangan dengan Permen. Hal ini di dasarkan pada pemikiran bahwa Permendag memberikan opsi (bukan larangan) para pihak, yaitu apakah penerima waralaba dilarang atau diperkenankan membuat perjanjian waralaba lanjutan. Jika ada kewajiban bagi penerima waralaba untuk merahasiakan serta tidak memberitahukan kepada pihak ketiga apa yang diperolehnya dari franchisor, maka dalam perjanjian harus dicantumkan keterangan-keterangan apa sajakah yang harus diberikan oleh pemberi waralaba kepada penerima waralaba.

Pada saat pemberi waralaba terikat pada suatu perjanjian waralaba dengan penerima waralaba, pemberi waralaba tidak diperkenankan untuk mewaralabakan produk atau jasa yang sama dengan merek dagang yang sama kepada penerima waralaba lainnya di lokasi-lokasi yang berdekatan. Apabila hal tersebut terjadi dapat mengakibatkan persaingan antar unit waralaba di lokasi-lokasi tersebut.Pembatasan ini juga berlaku bagi penerima waralaba terhadap penerima waralaba lanjutan.

Dalam pemberian hak eksklusif untuk mempergunakan dan/atau memasarkan produk atau jasa di daerah tertentu, para pihak juga harus mempertimbangkan peraturan-peraturan yang berkenaan dengan persaingan usaha tidak sehat. Suatu hak eksklusif untuk mempergunakan dan/atau memasarkan produk atau jasa dapat termasuk ke dalam kategori kegiatan-kegiatan yang dilarang berdasarkan Undang-Undang No. 5 Tahun 1999 yang bertujuan untuk menghapuskan praktik monopoli dan persaingan usaha tidak sehat di Indonesia.

Jika pemberi waralaba mengakhiri perjanjian waralaba sebelum jangka waktunya berakhir, maka pemberi waralaba dapat 
membuat perjanjian waralaba lain apabila semua masalah yang timbul dari perjanjian yang berakhir tersebut telah diselesaikan dan dinyatakan dengan jelas dalam suatu surat pernyataan bersama antara para pihak yang terlibat.

Dengan demikian, pada dasarnya waralaba berkenaan dengan pemberian izin oleh pemberi waralaba kepada orang lain atau beberapa orang untuk menggunakan sistem atau cara pengoperasian suatu bisnis. Pemberian izin ini meliputi penggunaan hak-hak pemilik waralaba yang berada di bidang hak milik intelektual (intellectual property rights). Pemberian izin ini kadang kala disebut dengan pemberian lisensi.

Perjanjian lisensi biasa tidak sama dengan perjanjian waralaba. Pada perjanjian lisensi biasa hanya meliputi satu bidang kegiatan saja, misalnya pemberian izin lisensi bagi penggunaan merek tertentu atau pun lisensi pembuatan satu/beberapa jenis barang tertentu. Sedangkan pada perjanjian waralaba, pemberian lisensi melibatkan berbagai macam hak milik intelektual, seperti nama perniagaan, merek, model dan desain.

Sebenarnya waralaba memiliki ruang lingkup yang lebih luas dari sekedar pemberian izin lisensi penggunaan atau penjualan atau pembuatan satu atau beberapa jenis barang tertentu saja. Selain hal tersebut di atas, apabila dalam perjanjian waralaba tidak diikuti dengan perjanjian antara karyawan dengan perusahaan penerima waralaba untuk melindungi rahasia dagang maka hal ini akan menjadi permasalahan tersendiri. Dalam keadaan ini penerima waralaba mungkin saja tidak melakukan pelanggaran HAKI akan tetapi karyawan adalah pihak ketiga yang akan berpotensi untuk melakukan peniruan terhadap ciri khas dari pemberi waralaba, mengingat karyawan dari perusahaan 
waralaba juga mengetahui secara persis rahasia dagang dari perusahaan tersebut. Oleh karena itu maka sebaiknya dilakukan pula perjanjian antara perusahaan dan karyawan untuk melindungi rahasia dagang suatu waralaba. Untuk itu menurut penulis seharus dibuat pula perjanjian antara karyawan dengan perusahaan penerima waralaba untuk melindungi rahasia dagang. Perjanjian tersebut di antara harus memuat kesepakatan sebagai berikut:

1. Karyawan harus dari waktu ke waktu dan/atau berdasarkan waktu yang ditentukan oleh perusahaan secara lengkap memberitahukan dan memaparkan kepada perusahaan, secara tertulis, seluruh hasil karya, pekerjaan, penemuan, desain, perbaikan dalam bentuk apapun, yang telah dibuat, dihasilkan dan/atau dikembangkan oleh karyawan. (termasuk dari mana sebelum perjanjian ini diadakan) dan/atau yang kelak akan dibuat, dihasilkan dan/atau dikembangkan oleh karyawan, selama masa karyawan bekerja di perusahaan, yang berhubungan dengan usaha-usaha yang dijalankan oleh perusahaan dan/atau setiap pekerjaan atau usaha yang dijalankan oleh perusahaan. Hal ini selanjutnya disebut sebagai "Invensi"

2. Perjanjian ini berlaku terhadap semua invensi yang telah dan/atau akan dibuat, dihasilkan dan/atau, baik yang memenuhi atau tidak memenuhi persyaratan dalam hak paten, hak cipta, hak merek, rahasia dagang atau perlindungan hukum lainnya baik yang telah dibuat, dihasilkan dan/atau dikembangkan selama dan/atau di luar jam kerja reguler di perusahaan, Baik yang telah dibuat, 
dihasilkan dan/atau dikembangkan dengan menggunakan fasilitas perusahaan atau di luar fasilitas Perusahaan.

3. Seluruh Invensi akan menjadi Hak milik tunggal dan ekslusif dari perusahaan dan berkaitan dengan tujuan perjanjian ini akan dianggap sebagai bagian dari INFORMASI RAHASIA DAGANG, baik yang telah atau belum diwujudkan dalam bentuk nyata.

4. Karyawan setuju bahwa satiap Invensi akan dianggap sebagai PENEMUAN ATAU CIPTAAN YANG DIBUAT DALAM HUBUNGAN KERJA ATAU BERDASARKAN PESANAN (Work Made For Hire) dan perusahaan akan dianggap sebagai penemu atau pencipta dari ciptaan tersebut. Dalam situasi di mana suatu Invensi atau ciptaan ditetapkan bukan sebagai PENEMU ATAU CIPTAAN YANG DIBUAT DALAM HUBUNGAN KERJA ATAU BERDASARKAN PESANAN (Work Made For Hire), maka karyawan, tanpa dapat mencabut kembali, menyerahkan dan menstransfer seluruh hak kepemilikan atas ciptaan tersebut kepada perusahaan.

5. Karyawan akan membantu dan bekerjasama dengan perusahaan baik selama masa karyawan bekerja di perusahaan dan/atau setelah karyawan tidak lagi bekerja di perusahaan, dengan tanggungan biaya secara penuh dari perusahaan, agar perusahaan mendapatkan dan memiliki seluruh hak paten, hak cipta, hak merek, rahasia dagang atau perlindungan hukum lainnya sehubungan dengan Invensi tersebut.

6. Karyawan akan menandatangani semua dokumen-dokumen yang berhubungan dengan Invensi dan melakukan hal-hal yang dianggap perlu dalam rangka mendapatkan 
perlindungan hukum bagi Invensi tersebut dan menyerahkan hak kepemilikan secara penuh dan ekslusif kepada perusahaan untuk seluruh lnvensi, dalam menghadapi gugatan-gugatan hukum apapun dari pihakpihak lain terhadap perusahaan.

7. Karyawan tidak akan mendapatkan kompensasi tambahan dalam bentuk apapun atas setiap dan seluruh Invensi yang dihasilkan karyawan bekerja di perusahaan.

8. Karyawan menyatakan bahwa selama masa karyawan bekerja di perusahaan, karyawan tidak pernah dan/atau tidak akan membeberkan kepada perusahaan, rahasia dagang apapun, informasi rahasia dan/atau informasi yang menjadi hak milik pihak manapun juga, secara umum tidak beredar secara luas di khalayak luas dan publik. Karyawan menyatakan bahwa seluruh tindakan yang diisyaratkan oleh perjanjian ini untuk dijalankan oleh karyawan, dan dalam kapasitas kewajiban sebagai Karyawan di perusahaan, tidak akan melanggar Perjanjian Larangan Pengungkapan Informasi Rahasia (Confidentiality or Non- Disclosure Agreement). Perjanjian Penyerahan Hak atas Kekayaan Intelektual (Assignment of Intellectual Property Rights Agreement) dan/atau perjanjianperjanjian lainnya dengan siapapun yang pernah mempergunakan jasa karyawan sebelumnya, baik karyawan berposisi sebagai tidak terbatas pada karyawan,konsultan, kontraktor. Karyawan akan menanggung segala tanggung jawab dan melepaskan perusahaan dari segala tuntutan yang mungkin muncul dari pihak manapun di kemudian hari.

9. Penalti berbentuk ganti rugi sebesar jumlah tertentu akan dikenakan terhadap Karyawan dalam situasi di mana 
Karyawan melakukan pelanggaran terhadap isi dari perjanjian ini.

10. Karyawan menyetujui dan memberikan izin kepada perusahaan untuk menotifikasi perusahaan baru tempat Karyawan bekerja atau kepada siapapun yang mempekerjakan karyawan di kemudian hari, akan adanya kewajiban-kewajiban dari karyawan terhadap perusahaan, sebagaimana yang tercantum dalam perjanjian ini.

11. Setiap klausul dalam perjanjian ini dan klausul dalam perjanjian ini secara keseluruhan akan mempunyai kekuatan hukum yang mengikat secara penuh terhadap pihak pewaris, eksekutor, administrator dan perwakilan hukum lainnya dari pihak karyawan. Hal tersebut dimaksudkan bagi keutuhan penjagaan kepentingan perusahaan, para pengganti yang akan menduduki jabatan penting di perusahaan dan bagi orang-orang atau lembaga-lembaga atau bentuk-bentuk identitas lainnya yang ditunjuk perusahaan.

12. Karyawan menyatakan bahwa karyawan cakap menurut hukum dan berhak untuk menjadi pihak dalam perjanjian ini.

13. Setiap klausul dalam perjanjian ini adalah terpisah dan berdiri sendiri. Apabila ada klausul yang dinyatakan tidak berlaku atau tidak dapat melaksanakan menurut hukum yang berlaku, maka klausul-klausul lainnya tidak akan terpengaruh dan klausul yang dinyatakan tidak berlaku atau tidak dapat melaksanakan menurut hukum akan diubah agar menjadi sah dan dapat dilaksanakan semaksimal mungkin menurut hukum.

14. Perjanjian ini dibuat dan berlaku berdasarkan hukum yang berlaku di Republik Indonesia. 
15. Dengan ditandatanganinya perjanjian ini secara sah oleh kedua belah pihak, maka semua perjanjian sejenis sebelumnya, baik yang secara lisan dan/atau tertulis, dianggap tidak berlaku lagi.

16. Ketentuan lainnya yang belum diatur dalam perjanjian ini akan diatur dalam adendum atau perjanjian terpisah, disesuaikan dengan kebutuhan perusahaan, dan merupakan satuan kesatuan bagian yang tidak terpisahkan dengan perjanjian ini.

17. Karyawan menyatakan bahwa :

a. Karyawan telah membaca, mengerti dan bersedia untuk melaksanakan sepenuhnya perjanjian ini.

b. Karyawan telah diberikan kesempatan untuk meminta keterangan dan penjelasan lebih lanjut tentang hal-hal yang kurang dimengerti dari perjanjian ini.

c. Perjanjian ini dibuat dalam 2 (dua) rangkap dan dibubuhi materai secukupnya, yang mana masing-masing perjanjian mempunyai kekuatan yang sama.

d. Kewajiban-kewajiban karyawan dalam perjanjian ini tetap berlaku secara penuh terhadap karyawan, walaupun karyawan sudah tidak bekerja pada perusahaan dengan alasan apapun juga.

Hambatan lainnya yang dapat terjadi dalam Perjanjian Waralaba menurut penulis, adalah pada saat pelaku usaha baru pertama kali melakukan usaha waralaba, baik dalam kapasitas sebagai pemberi waralaba maupun penerima waralaba. Hambatan tersebut dapat terjadi oleh karena para pihak belum memahami aspek-aspek hukum dari waralaba, sehingga tidak memiliki pedoman yang baik. Keadaan ini dapat berdampak pada 
perlindungan hukum HAKI dalam waralaba, mengingat pelaku usaha tidak menyadari arti penting dari perlindungan HAKI tersebut sebagai inti dari suatu waralaba. Ketidaktahuan para pelaku usaha waralaba dapat terlihat dalam penyusunan Perjanjian Waralaba, dimana dalam Perjanjian Waralaba tersebut, tidak terdapat klausula khusus yang mengatur tentang perlindungan HAKI dari waralaba tersebut. Dengan demikian akan terdapat kelemahan dari Perjanjian tersebut, yang akan sangat mungkin dimanfaatkan oleh pihak-pihak tertentu yang berakibat terjadinya permasalahan hukum, khsususnya pelanggaran HAKI, seperti rahasia dagang suatu waralaba.

Permasalahan ini akan teratasi apabila pelaku usaha waralaba memakai jasa konsultan untuk mendampinginya dalam melakukan negosiasi bisnis dan pembuatan perjanjian. Penulis melihat arti penting seorang notaris dalam merumuskan Perjanjian Waralaba, agar dapat menjadi suatu perjanjian yang seimbang dan mampu memberikan perlindungan hukum bagi pihak yang membuatnya, khususnya dalam bidang HAKI. Oleh karena itu untuk dapat berjalannya suatu bisnis waralaba dengan baik maka para pelakunya harus mempergunakan konsultan ahli waralaba dan konsultan hukum atau notaris, untuk menghindari terjadinya permasalahan hukum dikemudian hari.

\section{KESIMPULAN}

1. Bentuk Hukum Perjanjian Waralaba Di Cv. Rocket Fried Chicken Sesuai Dengan Pasal 4 Ayat (1) Dan (2) Peraturan Pemerintah No. 42 Tahun 2007 Tentang Waralaba, Waralaba Diselenggarakan Berdasarkan Perjanjian Tertulis Antara Pemberi Waralaba Dengan Penerima Waralaba Dengan Memperhatikan Hukum Indonesia. Dalam Hal Perjanjian 
Sebagaimana Dimaksud Pada Ayat (1) Ditulis Dalam Bahasa Asing, Perjanjian Tersebut Harus Diterjemahkan Ke Dalam Bahasa Indonesia. Sebelum Pembuatan Perjanjian Waralaba Antara Cv. Rocket Fried Chicken Dengan Waralaba Atau Kuasanya Dalam Hal Ini Dengan Wajib Mendaftarkan Propektus Penawaran Waralaba Sebelum Membuat Perjanjian Waralaba Dengan Penerima Waralaba. Pemberi Waralaba Juga Harus Memberikan Propektus Penawaran Waralaba Kepada Calon Penerima Waralaba Paling Singkat 2 (Dua) Minggu Sebelum Penandatanganan Perjanjian Waralaba. Propektus Penawaran Waralaba Adalah Keterangan Tertulis Dari Pemberi Waralaba Yang Sedikitnya Adalah Keterangan Tertulis Dari Pemberi Waralaba Yang Sedikittnya Menjelaskan Tentang Identitas, Legalitas, Sejarah Kegiatan, Struktur Organisasi, Keuangan, Jumlah Tempat Usaha, Daftar Penerima Waralaba, Hak Dan Kewajiban Pemberi Dan Penerima Waralaba. Bahwa Perjanjian Franchise Adalah Merupakan Perjanjian Istimewa Bagi Para Pihak Yang Terikat Di Dalamnya, Karena Berkaitan Dengan Hak-Hak Kekayaan Intelektual.

2. Kendala-Kendala Yang Dihadapi Dalam Perjanjian Waralaba Yaitu Adanya Perjanjian Yang Tidak Diikuti Dengan Perjanjian Antara Karyawan Dengan Perusahaan Penerima Waralaba Untuk Melindungi Rahasia Dagang Maka Sebaiknya Dilakukan Perjanjian Antara Perusahaan Dan Karyawan Guna Melindungi Rahasia Dagang. Kendala Lain Adalah Apabila Pelaku Usaha Baru Pertama Kali Melakukan Usaha Waralaba Maka Para Pihak Belum Memahami Aspek-Aspek Hukum Dari Waralaba Maka Pelaku Usaha Waralaba Perlu Menggunakan Jasa Konsultan Hukum Atau Notaries Untuk Menghindari 
Permasalahan Hukum Yang Dihadapi Dikemudian Hari.

\section{DAFTAR PUSTAKA}

Adi, Rianto, 2012, Sosiologi Hukum Kajian Hukum Secara Sosiologis Yayasan Pustaka Obor Indonesia, Jakarta

A.Qiram Syamsudin Meliala, Pokok-pokok Hukum Perjanjian Beserta Perkembangannya, Yogyakarta, Liberty, 1985.

Abdul Kadir Muhammad, Hukum Perikatan, Bandung, Citra Aditya Bakti, 1992.

Abdul R. Saliman, Hukum Bisnis Untuk Perusahaan, Teori dan Contoh Kasus, Jakarta, Prenada

Media Group, 2005.

Adrian Sutedi, Hukum Waralaba, Jakarta, Ghalia Indonesia, 2008.

Amir Karamoy, Sukses Usaha Lewat Waralaba, PT Jurnalindo Aksara Jakarta, Grafika, 1996.

Anggraeni, Hukum Perikatan (Perikatan yang Lahir dari Perjanjian), Semarang,Badan Penerbit

Undip, 2003.

Arus Akbar Silondae dan Andi Fariana, Aspek Hukum Dalam Ekonomi \& Bisnis, Mitra Wacana

Media, Badan Penerbit Undip.

Gerald J. Postema, Bentham And The Common Law dalam Abdul Manan,

Reformasi Hukum Islam di Indonesia, Jakarta, Raja Grafindo Persada.

Gunawan Widjaya, Lisensi Atau Waralaba, Suatu Panduan Praktis.

Handowo Dipo, Sukses Usaha Memperoleh Dana, dengan Konsentrasi, 1993.

J. Queen, Pedoman Membeli dan Menjalankan Franchise, Terjemah Jakarta, PT Elex Media

Komputindo.

Johannes Ibrahim dan Lindawati Sewu, Hukum Bisnis dalam Persepsi Manusia Modern, 
Bandung, Refika Aditama.

Leonardus Saiman, Kewirausahaan teori, praktik, dan Kasuskasus, Penerbit Salemba Empat.

Lili Rasjidi dan Ira Thania Rasjidi, Pengantar Filsafat Hukum, Bandung.

Martin Mendelsohn, Franchising: Petunjuk Praktis bagi Franchisor dan Franchisee, Jakarta,

PT. Pustaka Binaman Perssindo.

Mochtar Kusumaatmadja, Pengantar Ilmu hukum, Suatu Pengenalan Pertama

Ruang Lingkup Berlakunya Hukum, Jakarta.

Peter Mahmud Marzuki, Pengantar Ilmu Hukum, Jakarta, Kencana Prenada

Media Group.

Purwahid Patrik, Asas-asas Itikad Baik dan Kepatutan Dalam Perjanjian, Semarang.

Dasar-dasar Hukum Perikatan, Perikatan yang lahir dari perjanjian

dan dari Undang-Undang, Bandung, Mandar Maju.

R. Setiawan, Pokok-pokok Hukum Perikatan, Bandung, Bina Cipta.

R. Subekti, Hukum Perjanjian, Jakarta, Intermasa.

R. Wiryono Projodikoro, Asas-asas Hukum Perjanjian, Bandung,Sumur.

Richard Burton Simatupang, Aspek Hukum dalam Bisnis, Jakarta, Rineka Cipta.

Setiawan, Segi-segi Hukum Trade Mark dan Licensing, Varia Peradilan.

UNDANG-UNDANG

Peraturan Pemerintah No.42 Tahun 2007 tentang Waralaba.

Peraturan Mentri No.31/M-DAG/PER/2008 tentang Penyelenggaraan Waralaba.

Kepmenperindag No.259/MPP/KEP/1997 tentang Tata Cara Pelaksanaan Pendaftaran Usaha Waralaba 


\section{ARTIKEL}

Anonymous, Franchise dan Pengertianya (Harian Pikiran Rakyat), 3 Februari 2007.

Anonymous, Mc Donald's Hamburger: Suatu Jaringan Franchise Internasional Kini telah Memiliki

Outlet di Jakarta (Harian Kompas), 21 Januari 1990.

Anonymous, Mengenal Istilah Waralaba (http://www.wirausaha.com) Dalam Perjanjian Baku (Majalah

Ilmiah Fakultas Hukum Universitas Diponegoro) Gunawan Widjaja, SalamFrinchise.com, 8 April 2008.

MajalahInfo Franchise,www.majalahfranchise.com, 16 Juni 2008.

Roy Sembel dan Tedy Ferdiansyah, Tujuh Jurus Pendanaan di Tahun Kuda Air, Jakarta, USAHAWAN No. 03 Th. XXXI, (2002).

Siti Malikhatun Badriyah, Perlindungan Hukum Terhadap Pihak Adherent Vol.XXX NO. 1 Januari - Maret 2001.

Yohanes Heidy Purnama, SalamFrinchise.com,1 Maret 2008. 

